\title{
Predicting effects of plantation expansion on streamflow regime for catchments in Australia
}

\author{
L. Zhang, F. F. Zhao, and A. E. Brown \\ CSIRO Water for a Healthy Country Flagship, CSIRO Land and Water, Canberra, ACT, Australia \\ Correspondence to: L. Zhang (lu.zhang@csiro.au)
}

Received: 3 January 2012 - Published in Hydrol. Earth Syst. Sci. Discuss.: 10 January 2012

Revised: 22 May 2012 - Accepted: 16 June 2012 - Published: 16 July 2012

\begin{abstract}
The effect of plantations on mean annual streamflow is well understood and, there are robust methods available for assessing the impact. Plantations also affect streamflow regime, leading to reductions in low flow and increased number of zero-flow days. Understanding changes in streamflow regime following plantation expansion is important for developing water resources and environmental flow strategy. This study evaluated the impacts of plantations on streamflow regime from 15 catchments in Australia. The selected catchments range in size from 0.6 to $1136 \mathrm{~km}^{2}$ and represent different climatic conditions and management practices. The catchments have at least $20 \mathrm{yr}$ and in most cases $35 \mathrm{yr}$ of continuous daily streamflow data and well documented plantation records. Catchments with perennial streamflow in the pre-treatment periods showed relatively uniform reductions in most flows after plantation expansions, whereas catchments with ephemeral streamflow showed more dramatic reductions in low flows, leading to an increased number of zero-flow days. The Forest Cover Flow Change (FCFC) model was tested using the data from the selected catchments and comparison of predicted and observed flow duration curves showed that 14 of the 15 catchments have coefficients of efficiency greater than 0.8 . The results indicate that the model is capable of predicting plantation impacts on streamflow regime.
\end{abstract}

\section{Introduction}

Our understanding of the vegetation impact on mean annual water yield is well advanced, and there are robust methods available for assessing the impact (Bosch and Hewlett, 1982; Zhang et al., 2001; Brown et al., 2005; Zhao et al., 2010; Wei and Zhang, 2010). Recently, a number of studies focused on changes in flow regime following vegetation cover changes and showed different responses in high flows and low flows (Lane et al., 2005; Brown et al., 2006). It has been recognised that there is a need to make predictions of changes in streamflow regime for water security and ecosystem assessments (Brown et al., 2007). Streamflow regime has been used to describe hydrological characteristics encompassing seasonal pattern, magnitude, frequency, duration, and interannual variation of streamflow (Haines et al., 1988; Sanborn and Bledsoe, 2006). An important step in predicting changes in streamflow regime is to select an appropriate statistic that can be used to describe various streamflow regimes found in catchments. In this study, streamflow regime refers to distribution of streamflow as represented by a flow duration curve (FDC). The flow duration curve (FDC) approach has been adopted as it provides a statistical method for describing flow distribution and more importantly allows for identification of differences between two streamflow time series (Smakhtin, 2001; Brown et al., 2005, 2006). Another useful feature of an FDC is the ability to easily display flow variability and its direct application in water allocation analysis (Brown et al., 2007).

While change to mean annual water yield is important for the purpose of regional and basin-wide planning, the impacts of vegetation change on streamflow regime can be more significant from both water security and environmental flow perspectives. For example, if there is a large area of afforestation in catchments, will this affect water security or environmental flows during extended dry periods? A commonly used approach for predicting the impact of afforestation on streamflow is to rely on detailed physically based models (Baron et al., 1998; Legesse et al., 2003) or conceptual models derived 
from paired catchment studies (Sivapalan et al., 1996; Scott and Smith, 1997; Hundecha and Bárdossy, 2004). Use of physically based models in large catchments is problematic and impractical because of data requirements. It is desirable to use conceptual models that can be accurately supported by available data.

It is generally understood that plantations affect not only rainfall interception, which directly influences surface runoff, but also deep drainage, which in turn determines the amount of base-flow in a catchment. However, it is difficult to quantify these changes in catchments where no measurements are available since the relative role of plantations in controlling these processes depends upon climate, vegetation, soil, and other catchment characteristics. In this study, a simple conceptual model developed by Brown et al. (2006), the Forest Cover Flow Change model (FCFC), was considered. The FCFC model was designed to adjust a time series of observed or simulated daily flow to account for changes in forest cover, and the model was developed based on data from paired catchment studies. The FCFC model was developed for a practical purpose, namely predicting changes in flow duration curves following plantation expansions with minimum data requirements. As a result, the model is simple in its process representation. This raises the issue of transferability of the model to other catchments or regions for predicting plantation impact on streamflow regime.

Plantation forestry is an important land use in Australia, and the nationwide plantation area has increased by over $70 \%$ since 1994 and reached a total area of nearly 2 million hectares in 2008 (BRS, 2009). Some of the plantations were developed in catchments where gauged streamflow data are available, and this provides an opportunity to investigate streamflow response to plantation development (Zhang et al., 2011). Unlike paired experimental catchments that are generally less than $1 \mathrm{~km}^{2}$ in size, the plantation affected catchments used in this study represent typical catchments where water resources decisions need to be made. Also these catchments can be used to quantify plantation impact on streamflow regime, providing a unique opportunity for testing the FCFC model in large catchments.

The objectives of this paper are to (1) determine changes in flow duration curves from Australian catchments affected by plantation development, and (2) test the FCFC model in predicting the effects of plantation expansion on streamflow regime. The catchments used in this study range in size from 0.6 to $1136 \mathrm{~km}^{2}$, representing typical catchments where land use and water resources decisions need to be made.

\section{Methods}

\subsection{Flow Duration Curve (FDC)}

A FDC represents the relationship between the magnitude and frequency of daily, weekly, or monthly (or some other time interval) streamflow; it provides a measurement of the proportion of time a given streamflow was equaled or exceeded in the period of measurement. A FDC provides a simple, yet comprehensive graphical view of the overall historical variability associated with streamflow and is the complement of the cumulative distribution function of daily streamflow.

A FDC can be constructed from daily streamflow data by ranking the flows from the maximum to minimum with each flow plotted against the percentage of time it is exceeded. It provides a graphical and statistical summary of the streamflow variability and distribution, with the shape being determined by rainfall pattern, catchment size, and the physiographic characteristics of the catchment. The shape of the FDC is also influenced by water resources development and land-use type (Smakhtin, 1999).

\subsection{Forest Cover Flow Change model (FCFC)}

The Forest Cover Flow Change methodology (FCFC) was developed to predict changes in a daily flow duration curve (FDC) following a change in forest cover (Brown et al., 2006; Brown, 2008). The inputs to FCFC are daily values of rainfall, potential evaporation, and streamflow. FCFC also requires percentage forest cover during pre-treatment period and new percentage forest cover. The output from FCFC is a FDC associated with the new forest cover.

The FDC within FCFC is represented by a five parameter model as described by Best et al. (2003):

$Q(x)= \begin{cases}Q_{50}\left(10^{\frac{s}{c_{\mathrm{u}}}\left[\exp \left(F^{-1}\left(\frac{x}{\mathrm{CTF}}\right) c_{\mathrm{u}}\right)-1\right]}\right) & x \leq \frac{\mathrm{CTF}}{2} \\ Q_{50}\left(10^{\frac{s}{c_{1}}\left[\exp \left(F^{-1}\left(\frac{x}{\mathrm{CTF}}\right) c_{1}\right)-1\right]}\right) & \frac{\mathrm{CTF}}{2}<x<\mathrm{CTF} \\ 0 & x \geq \mathrm{CTF}\end{cases}$

where $Q(x)$ is the predicted percentile flow, $F^{-1}$ is the inverse of the standard normal cumulative distribution, $Q_{50}$ is the median of the non-zero flow or conditional median, CTF is the cease-to-flow percentile, $x$ is a percentile value $(0-$ $100 \%$ ), and $s, c_{\mathrm{u}}$, and $c_{1}$ are curve fitting parameters. The $s$, $c_{\mathrm{u}}$ and $c_{1}$ parameters relate to different sections of the FDC, $s$ being the slope at the origin of the normalised FDC (NFDC), and $c_{\mathrm{u}}$ and $c_{1}$ being the exponents for the upper and lower sections of the NFDC, respectively.

The FCFC model normalizes the FDC so that $Q_{50}=1$ and $\mathrm{CTF}=0$, and this facilitates the estimation of the remaining three parameters. Figure 1 shows the method used to normalise the FDC of perennial and ephemeral streams. Firstly, the cease-to-flow (CTF) percentile is established (Fig. 1a). The CTF percentile is defined as the ratio of the number of non-zero flow days to the total number of days. A nonzero flow day is defined as any day on which flow is greater than or equal to a specified threshold value (adopted here as $0.001 \mathrm{~mm} \mathrm{day}^{-1}$ ). A FDC is then constructed using only the days on which flow is greater than the threshold value, as streamflow measurements below this value are considered 


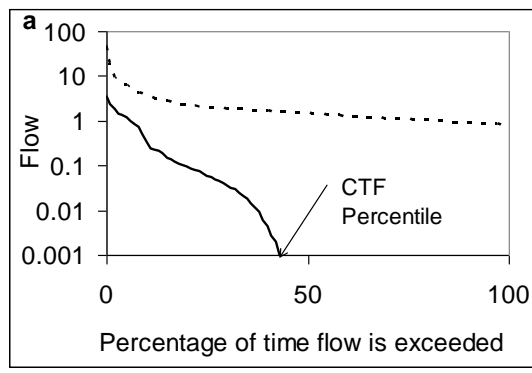

Ephemeral Stream - - - - - - Perennial Stream

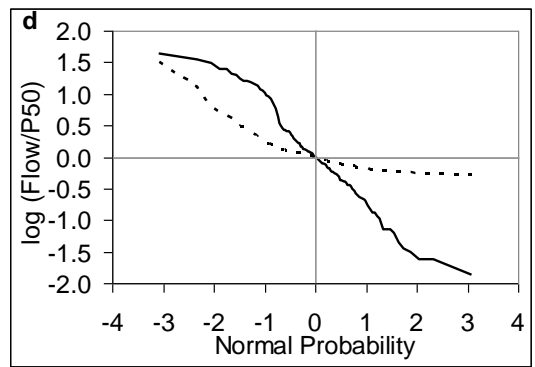

Determine the CTF percentile and determine the FDC for days when flow occurs
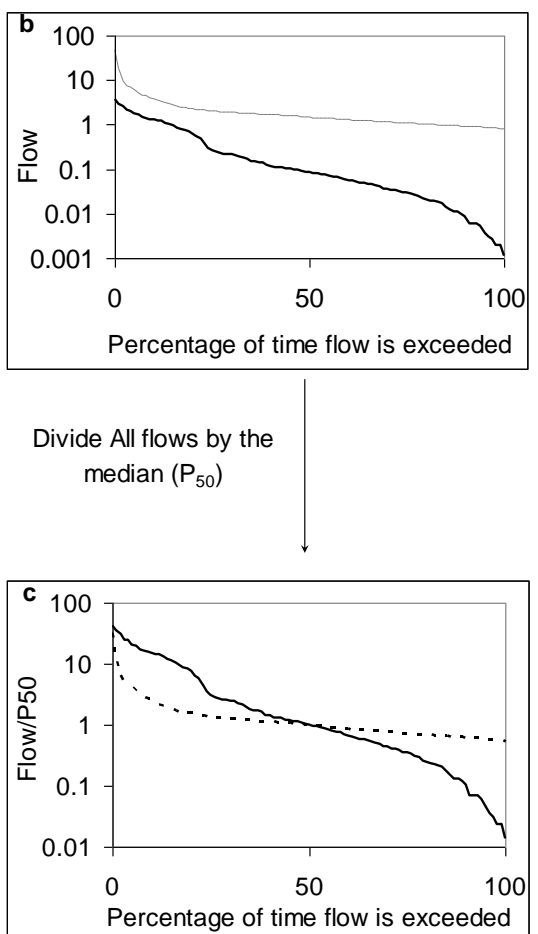

Fig. 1. Normalising the FDC to achieve common parameter space.

unreliable (Fig. 1b). The FDC is then normalised by dividing all flow values by the conditional median (Fig. 1c). Finally, the FDC is plotted in log-normal space (Fig. 1d) to produce a normalised FDC (NFDC). This normalisation procedure results in all of the NFDCs intersecting the origin.

The FCFC model optimizes the parameters by fitting Eq. (1) to measured daily FDC for each year of the flow record under pre-treatment conditions. The CTF and $Q_{50}$ are determined directly from the measured daily streamflow data, while the three remaining parameters $\left(s, c_{\mathrm{u}}, c_{1}\right)$ are obtained by maximizing the Nash and Sutcliffe efficiency of percentile flows in the log domain (Nash and Sutcliffe, 1970).

$E=1-\frac{\sum_{i=1}^{\mathrm{CTF}}\left(\log \left(Q_{\mathrm{o}}\right)-\log \left(Q_{\mathrm{p}}\right)\right)^{2}}{\sum_{i=1}^{\mathrm{CTF}}\left(\log \left(Q_{\mathrm{o}}\right)-\log \left(\overline{Q_{\mathrm{o}}}\right)\right)^{2}}$

where $Q_{\mathrm{o}}$ is the observed percentile flow and $Q_{\mathrm{p}}$ is the estimated percentile flow. The closer the coefficient of efficiency is to one, the better the fit. The logarithm of the values is used to give more weight to low flow values. As the CTF parameters is determined from the observed flow data, $E$ is calculated only between the first percentile and the CTF percentile, thus zero flows are not considered.

The upper exponent is then adjusted to ensure the area under the FDC and equals the observed annual streamflow. Once the parameters for each annual FDC are determined, the representative values of $s$ and $c_{\mathrm{u}}$ are estimated as the mean of each of the $s$ and $c_{\mathrm{u}}$ values for all the pre-treatment years.

To predict the effect of a forest cover change on a FDC, the model parameters are linked to a predicted change in mean annual streamflow using the method of Zhang et al. (2001). The linkage between mean annual streamflow and the FDC comes from the knowledge that the area under the FDC is equal to the mean annual streamflow (Fig. 2).

For a catchment with known forest cover change, the mean annual streamflow is predicted using the method of Zhang et al. (2001), and the information is then combined with the FDC parameterization to predict the changes in FDC associated with the forest cover change. This is done with the aid of a bucket model that simulates the relationship between rainfall, evapotranpsiration and streamflow as mediated by the soil water store. The bucket model is first calibrated against measured daily streamflow under pre-treatment conditions by adjusting the recession constant, maximum water storage capacity, and soil water storage threshold for evapotranspiration. The bucket model is then used to predict the CTF percentile and the 95th percentile flow under the new forest cover by changing soil water storage threshold. The lower exponent $\left(c_{1}\right)$ is determined from the slope of the normalized FDC, the CTF percentile for ephemeral streams and the 95th percentile flow for perennial streams. The parameters $s$ and $c_{\mathrm{u}}$ are assumed to be unchanged following a forest cover change as shown by Best et al. (2003). The 

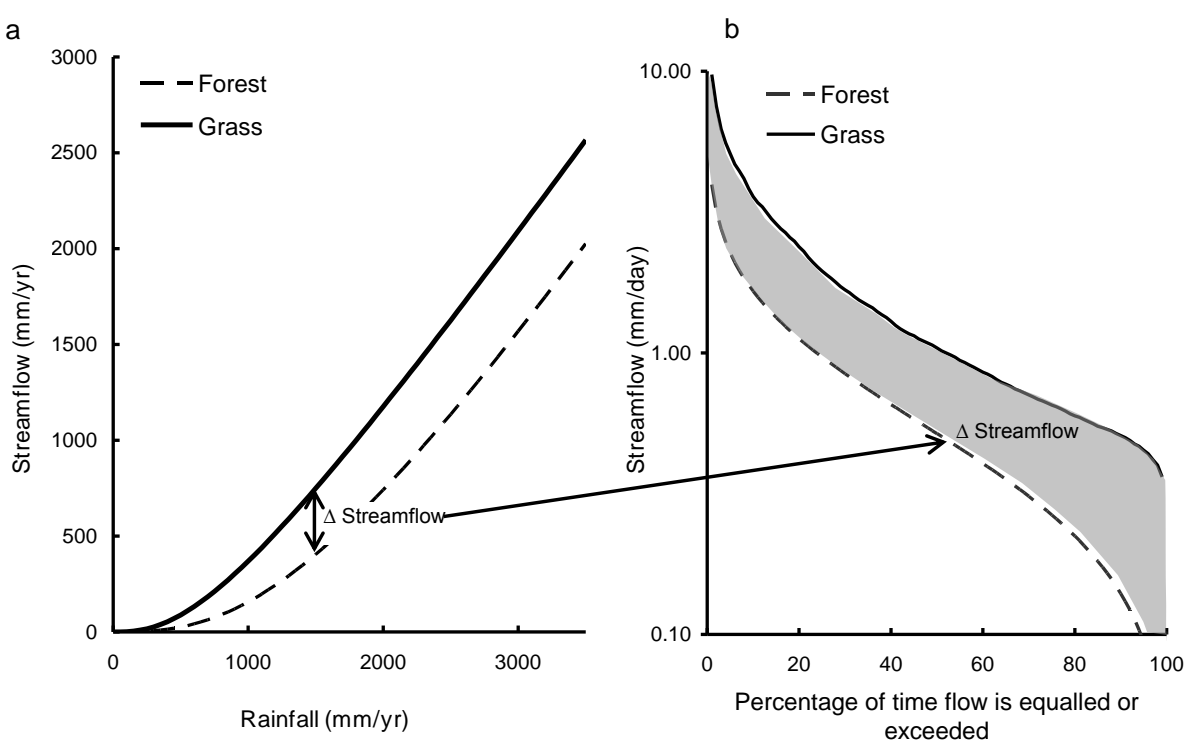

Fig. 2. Relationships between mean annual rainfall and streamflow for forested and grassed catchments as estimated by Zhang et al. (2001) (a). The change in mean annual streamflow for a catchment from grass to forest is indicated by $\Delta$ streamflow. Flow duration curves (FDC) for a catchment under forest and grass covers (b). The shaded area between the FDC for grass and FDC for forest is equal to $\Delta$ streamflow.

procedure described above provides an initial estimate of the FDC under the new forest cover. To ensure that the area under the FDC is equal to the mean annual streamflow predicted by the method of Zhang et al. (2001), the conditional median streamflow and the lower exponent are adjusted accordingly. The detailed description of FCFC can be found in Brown (2008).

\subsection{Time-trend analysis method}

One of the key componnents of the FCFC methodology is the method of Zhang et al. (2001) for estimating differences in mean annual streamflow for a catchment under different degrees of forest cover. The accuracy of Zhang et al. (2001) can be tested using time-trend analysis method, which is applicable to single catchment studies. Time-trend analysis method is primarily designed for estimating the differences in streamflow between pre-treatment and post-treatment periods (Bosch and Hewlett, 1982). In this method, rainfall and streamflow during the pre-treatment period are used to develop a statistical relationship, and this relationship is then used to estimate streamflow during the post-treatment period. The effect of forest cover change on streamflow is expressed as the difference between measured and predicted streamflow during the post-treatment period. Time-trend analysis method assumes that the rainfall-streamflow relationship developed for pre-treatment period will remain unchanged unless there is a forest cover change. Time-trend analysis method can be expressed as (Lee, 1980):
During the pre-treatment period,

$Q_{1}=f\left(P_{1}\right)$

and during the post-treatment period,

$Q_{2}^{\prime}=f\left(P_{2}\right)$

and

$\Delta Q^{\mathrm{veg}}=\overline{Q_{2}}-\overline{Q_{2}^{\prime}}$

where $P$ represents rainfall (mm), $Q$ represents measured streamflow $(\mathrm{mm}), Q^{\prime}$ is the predicted streamflow $(\mathrm{mm})$ with Eq. (4) based on data in the calibration period, and $\Delta Q^{\text {veg }}$ is the change in average annual streamflow $(\mathrm{mm})$ due to forest cover changes; subscripts 1 and 2 indicate the pretreatment and the post-treatment periods, respectively. The rainfall-streamflow relationship expressed by Eq. (3) can be either linear or non-linear, depending on data. In the case of non-linear relationship, the Tanh function is considered after Grayson et al. (1996).

\section{Catchment description and data}

\subsection{Catchment description}

To best represent the climatic conditions and management practices of these regions, 15 catchments have been selected in this study (Fig. 3) and they meet the criteria of having documented plantation areas and continuous streamflow $(Q)$ and climatic data. It is also ensured that the impacts of other 

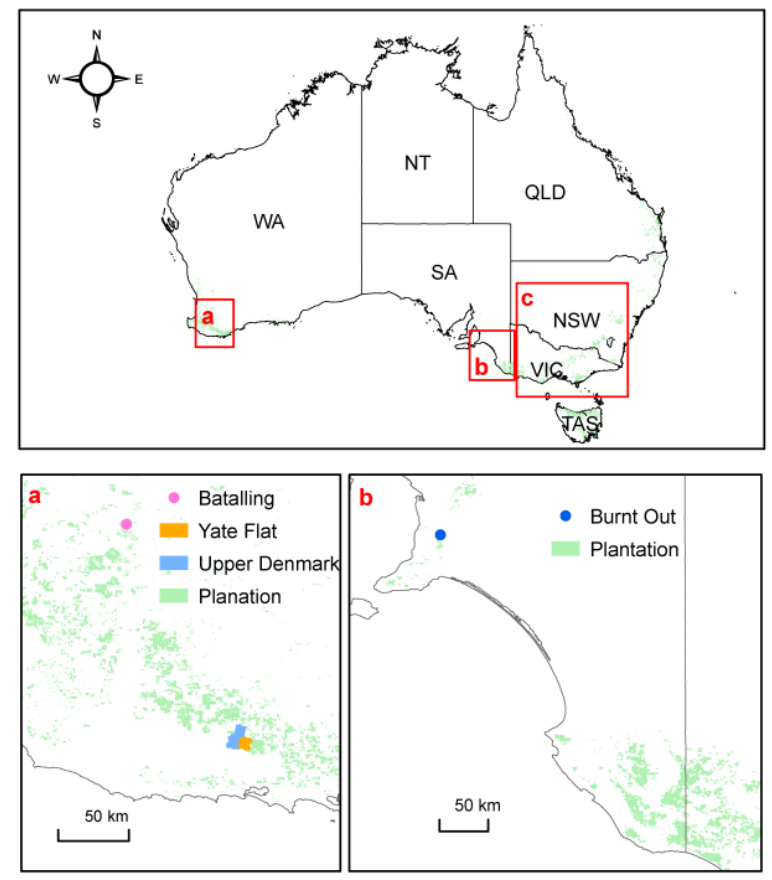

Fig. 3. Location map of the catchments.

land-use change (e.g. farm dams) and water extractions are minimal in the selected catchments.

The catchment areas range from $0.6 \mathrm{~km}^{2}$ to $1136 \mathrm{~km}^{2}$ with mean annual rainfall $(P)$ varying from $629 \mathrm{~mm}$ to $1011 \mathrm{~mm}$. The potential evaporation $\left(E_{0}\right)$ varies from $726 \mathrm{~mm}$ to $1117 \mathrm{~mm}$. The index of dryness (equal to $E_{0} / P$ ) ranges from 0.85 to 1.70 , and the runoff coefficient (equal to $Q / P$ ) varies from 0.10 to 0.42 . The selected catchments represent typical catchments where water resources decisions need to be made.

\subsection{Data}

\subsubsection{Streamflow data}

The catchments selected in this study have at least $20 \mathrm{yr}$ and in most cases $35 \mathrm{yr}$ of continuous daily streamflow data, except Burnt Out Creek which has several years of missing data. The streamflow data were obtained from different agencies. Detailed information on the gauging stations and the period of records are listed in Table 1.

\subsubsection{Climatic data}

Catchment averaged annual rainfall was estimated from gridded SILO rainfall data (Jefferey et al., 2001). The spatial resolution of the gridded daily rainfall data is $0.05^{\circ}$ based on interpolation of point measurements from over 6000 rainfall stations across Australia. The spatial coverage of the rainfall stations is reasonably good, particularly in the southeast Australia. The interpolation uses monthly rainfall data, ordinary

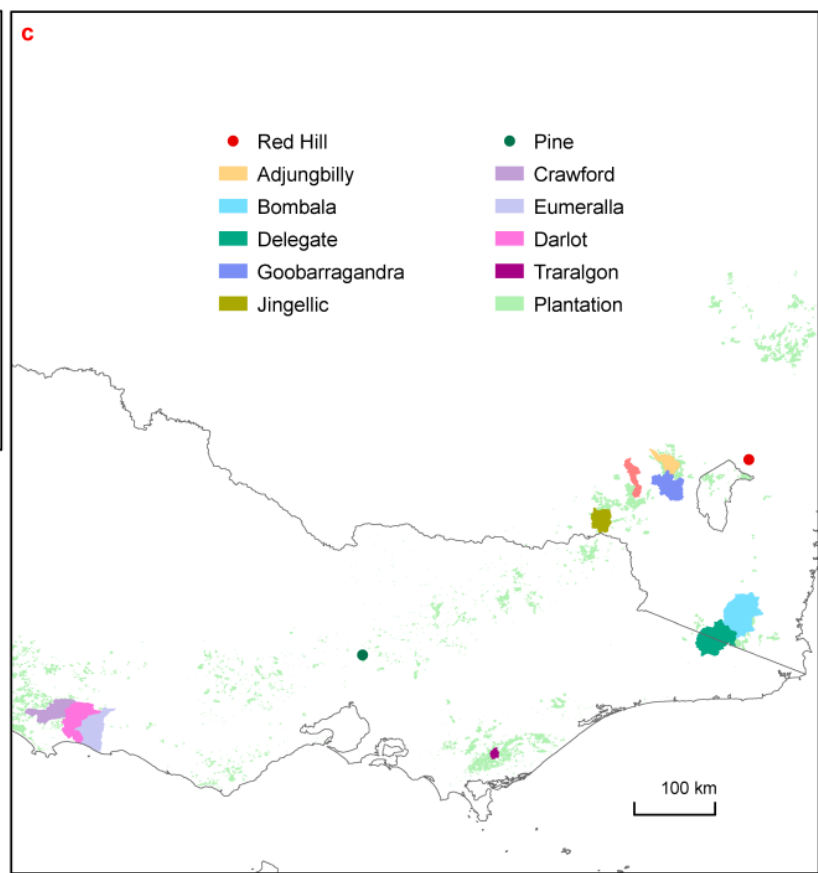

kriging with zero nugget, and a variable range. The method takes into account rainfall variations with elevation. Monthly rainfall for each $5 \times 5 \mathrm{~km}$ grid cell was converted to daily rainfall using daily rainfall distribution from the station closest to the grid cell (Jefferey et al., 2001). Catchment average rainfall was obtained by aggregating the SILO interpolated rainfall surfaces. Potential evaporation $\left(E_{0}\right)$ was estimated using measurements of class A pan evaporation obtained from SILO with the pan coefficient set to 0.75 following van Dijk (1985). For large catchments, average potential evaporation was obtained by averaging measurements of the class A pan evaporation from the stations within the catchments. For small catchments, measurements of the class A pan evaporation station closet to the catchments were used.

\subsubsection{Plantation and land-use data}

In order to investigate the effects of plantation expansions on streamflow, plantation data including plantation area and age for each of the selected catchments were provided by the $\mathrm{Bu}-$ reau of Rural Science and State agencies. Plantation development began in 1935 in Adjungbilly Creek mostly on native forest sites. Since 1982, planting started on land previously occupied by pastures; cumulative plantation cover (\%) over time for Adjungbilly Creek is shown in Fig. 4. The Batalling Creek catchment was $50 \%$ cleared for agriculture from 1940 to 1970 , and plantations were established in the catchment in 1985 with eucalyptus covering $38 \%$ of the cleared area (Bari and Ruprecht, 2003). The Burnt Out Creek catchment is located in the western Mount Lofty Ranges, South Australia, 
Table 1. Summary of selected catchments for plantation impact assessment.

\begin{tabular}{|c|c|c|c|c|c|c|c|c|c|c|}
\hline Catchment & $\begin{array}{l}\text { Gauging station } \\
\text { (ID) }\end{array}$ & State & Lat & Long & $\begin{array}{l}\text { Area } \\
\left(\mathrm{km}^{2}\right)\end{array}$ & $\begin{array}{r}\text { Rainfall } \\
(\mathrm{mm})\end{array}$ & $\begin{array}{r}E_{0} \\
(\mathrm{~mm})\end{array}$ & $\begin{array}{l}\text { Streamflow } \\
(\mathrm{mm})\end{array}$ & $\begin{array}{l}\text { Plantation cover } \\
(\%)\end{array}$ & $\begin{array}{l}\text { Calibration/testing } \\
\text { period }\end{array}$ \\
\hline Adjungbilly $\mathrm{Ck}$ & Darbalara (410038) & NSW & $35.02^{\circ} \mathrm{S}$ & $148.25^{\circ} \mathrm{E}$ & 391 & 1011 & 930 & 212 & 30.08 & 1933-1955/1995-2008 \\
\hline Batalling Ck & Batalling (612016) & WA & $33.32^{\circ} \mathrm{S}$ & $116.57^{\circ} \mathrm{E}$ & 16.64 & 629 & 1089 & 33 & 19 & 1979-1984/2000-2008 \\
\hline Bombala River & $\begin{array}{l}\text { Bombala/Falls } \\
(222019 / 222009)\end{array}$ & NSW & $37.00^{\circ} \mathrm{S}$ & $149.38^{\circ} \mathrm{E}$ & 559 & 783 & 779 & 181 & 26.8 & 1960-1978/1990-2000 \\
\hline Burnt Out Ck & (A5030529) & SA & $35.13^{\circ} \mathrm{S}$ & $138.70^{\circ} \mathrm{E}$ & 0.6 & 806 & 1117 & 28 & 67 & 1978-1982/2003-2007 \\
\hline Crawford River & $\begin{array}{l}\text { Lower Crawford } \\
(238235)\end{array}$ & VIC & $37.98^{\circ} \mathrm{S}$ & $141.46^{\circ} \mathrm{E}$ & 606 & 728 & 996 & 73 & 24.18 & 1971-1995/2004-2009 \\
\hline Darlot $\mathrm{Ck}$ & $\begin{array}{l}\text { Homerton Bridge } \\
(237205)\end{array}$ & VIC & $38.15^{\circ} \mathrm{S}$ & $141.77^{\circ} \mathrm{E}$ & 760 & 688 & 995 & 78 & 13.3 & 1970-1995/2004-2009 \\
\hline Delegate River & Quidong (222008) & NSW & $36.98^{\circ} \mathrm{S}$ & $149.05^{\circ} \mathrm{E}$ & 1135.7 & 859 & 726 & 134 & 14 & 1960-1978/1990-2000 \\
\hline Eumeralla River & Eumeralla (237206) & VIC & $38.26^{\circ} \mathrm{S}$ & $141.94^{\circ} \mathrm{E}$ & 502 & 725 & 987 & 56 & 19.84 & 1974-1995/2001-2008 \\
\hline Goobarragandra Ck & Lacmalac (410057) & NSW & $35.19^{\circ} \mathrm{S}$ & $148.20^{\circ} \mathrm{E}$ & 673 & 1009 & 952 & 419 & 8.32 & 1947-1955/1990-2008 \\
\hline Jingellic Ck & Jingellic (401013) & NSW & $35.53^{\circ} \mathrm{S}$ & $147.41^{\circ} \mathrm{E}$ & 390 & 838 & 1018 & 138 & 27.50 & 1966-1980/1996-2005 \\
\hline Pine $\mathrm{Ck}$ & Broadford (405290) & VIC & $37.29^{\circ} \mathrm{S}$ & $145.05^{\circ} \mathrm{E}$ & 3.2 & 629 & 953 & 37 & 88 & 1989-1991/1998-2009* \\
\hline Red Hill & Red Hill (410998) & NSW & $35.12^{\circ} \mathrm{S}$ & $149.35^{\circ} \mathrm{E}$ & 1.95 & 761 & 900 & 109 & 78 & $1990-1992 / 2001-2005^{*}$ \\
\hline Traralgon Ck & Koornalla (226410) & VIC & $38.32^{\circ} \mathrm{S}$ & $146.53^{\circ} \mathrm{E}$ & 89 & 959 & 827 & 272 & 58 & 1958-1965/1993-1999 \\
\hline $\begin{array}{l}\text { Upper Denmark } \\
\text { River }\end{array}$ & Kompup (603003) & WA & $34.70^{\circ} \mathrm{S}$ & $117.22^{\circ} \mathrm{E}$ & 243 & 742 & 1006 & 37 & 15.17 & $1989-1995 / 2004-2008$ \\
\hline Yate Flat Ck & Woonanup (603190) & WA & $33.70^{\circ} \mathrm{S}$ & $117.29^{\circ} \mathrm{E}$ & 56.32 & 742 & 1006 & 65 & 33.57 & 1989-1995/2004-2008 \\
\hline
\end{tabular}

* The calibration periods for Pine Creek and Red Hill are defined as the first three years since plantation development.

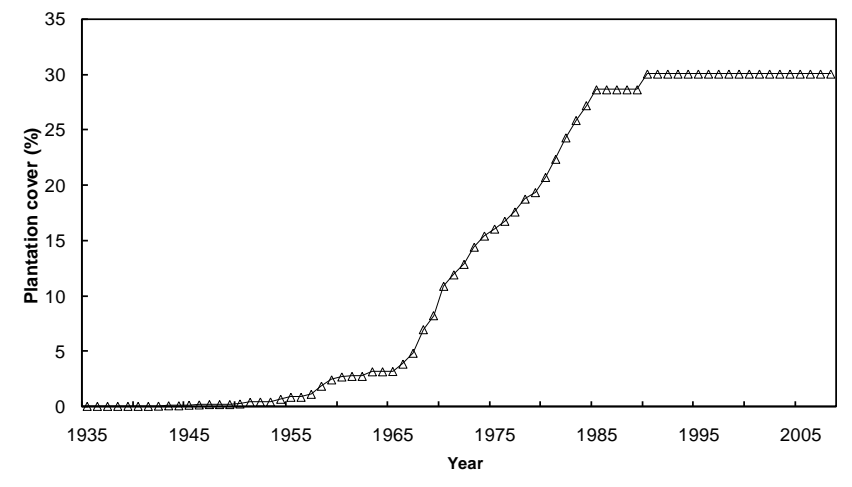

Fig. 4. Cumulative plantation cover (\%) over time for the Adjungbilly Creek catchment.

and around 40 ha or $67 \%$ of the catchment was replanted with $P$. radiata in November 1978 after a bushfire destroyed most of the plantations in the catchment (Greenwood and Cresswell, 2007). The Crawford River catchment has several main land uses including pastures, hardwood (blue gum: Eucalyptus globulus) and softwood (radiata pine: Pinus radiata) plantations, cropping and native forest. The area of plantations expanded significantly from less than 2000 ha in 1995 to 17000 ha or $25 \%$ of the catchment area in 2005. The Darlot Creek catchment and Eumeralla River catchment experienced similar plantation expansions with most plantations established since 1995. The area of land under pine plantations in the Delegate and Bombala catchments expanded to $11 \%$ and $14 \%$ of the catchment area, respectively (Tuteja et al., 2007). The Goobarragandra Creek catchment experienced plantation expansion in the period of 1965 to 1988 with about $8 \%$ of the catchment area planted. Plantation in the Jingellic Creek catchment did not start until 1965, and over 5000 ha of pasture land were converted to plantations in the period of 1982 to 1996 , representing $14 \%$ of the catchment area. In 1986 and 1987 the entire Pine Creek catchment was converted from open grassland to a Pinus radiata plantation (Linke et al., 1995; Lane et al., 2005). Red Hill is a small experimental catchment and over $70 \%$ of the catchment was planted with Pinus radiata in 1988 and 1989 (Major et al., 1998). The Traralgon Creek catchment was $70 \%$ planted with Eucalyptus regnans from the late 1950s (Feikema et al., 2008). The Upper Denmark and Yate Flat Creek are subcatchments of the Denmark River catchment. Clearing native forest for agricultural development in the catchments began in 1870, and $17 \%$ of the catchment had been cleared by 1957 (Bari et al., 2004). Tree planting in the catchments started in 1991 on previously pasture land (Bari et al., 2004), and by 2000 it had been almost completely replanted, mainly to E. globulus.

A summary of the plantation data for the selected catchments is listed in Table 1. Other information including landuse history, farm dams, and water diversions was also obtained for the selected catchments. Over the period of streamflow records, these catchments had minimum impact from farm dams and water extractions, and plantation expansion represents the most significant land-use change in these catchments.

\section{Results}

\subsection{Effects of plantation expansions on flow duration curves}

Figure 5 shows the daily flow duration curves for the pretreatment and post-treatment periods for the 15 selected 

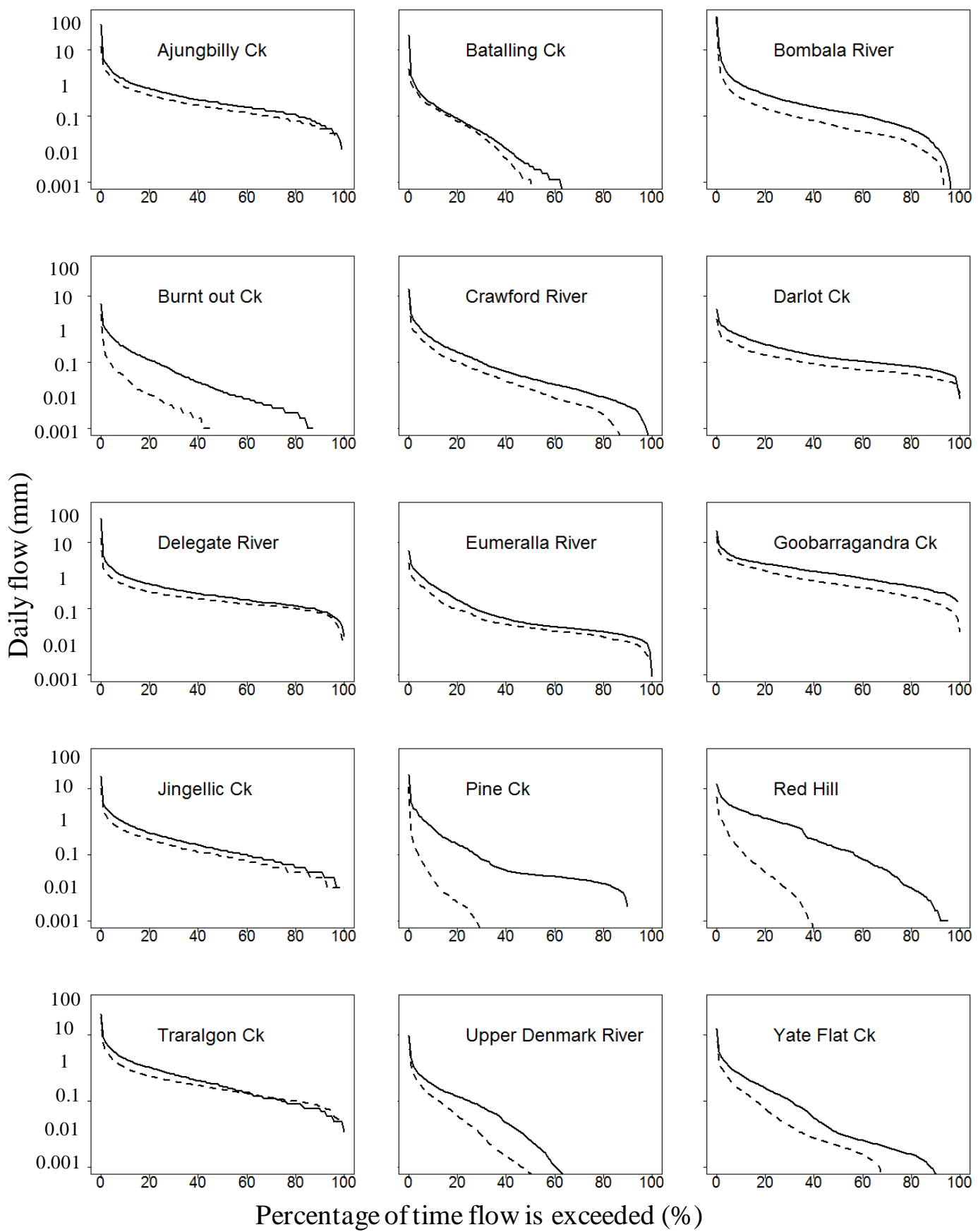

Fig. 5. Changes in daily flow duration curves for the selected catchments. The solid and dotted lines represent daily flow duration curves in the pre-treatment and post-treatment periods, respectively.

catchments. It is clear that all the catchments experienced various degrees of flow regime change. In general, the posttreatment period is drier than the pre-treatment period with a rainfall difference of up to $26 \%$; the rainfall difference alone would mean less streamflow in the post-treatment period. Zhang et al. (2011) estimated the effects of climate variability (e.g. rainfall) and platnation expansion on mean annual streamflow in these catchments and showed that climate variability accounted for $5 \%$ to $80 \%$ of the total streamflow reduction. In the pre-treatment period, most catchments had continuous streamflow (e.g. Adjungbilly Creek) while some exhibited ephemeral nature (e.g. Upper Denmark River). The perennial catchments are generally large in size with high rainfall, while the ephemeral catchments are small in size with low rainfall. Distribution of rainfall in relation to potential evaporation can also affect the streamflow regime. 
Table 2. Relative changes in High $\left(Q_{5}\right)$, Median $\left(Q_{50}\right)$, and Low flow $\left(Q_{95}\right)$ between pre-treatment and post-treatment periods.

\begin{tabular}{lrrr}
\hline Catchment & $\Delta Q_{5}(\%)$ & $\Delta Q_{50}(\%)$ & $\Delta Q_{95}(\%)$ \\
\hline Adjungbilly Ck & -33.7 & -31.7 & -20.2 \\
Batalling Ck & -23.5 & -60.0 & - \\
Bombala River & -61.2 & -65.8 & -99.2 \\
Burnt Out Ck & -86.6 & -100.0 & - \\
Crawford River & -50.2 & -53.1 & -100.0 \\
Darlot Ck & -51.8 & -43.5 & -40.7 \\
Delegate River & -48.5 & -27.2 & -12.4 \\
Eumeralla River & -49.5 & -25.0 & -38.7 \\
Goobarragandra Ck & -34.6 & -48.9 & -62.5 \\
Jingellic Ck & -45.1 & -32.1 & -38.8 \\
Pine Ck & -94.8 & -100.0 & - \\
Red Hill & -88.1 & -100.0 & -100.0 \\
Traralgon Ck & -47.4 & -22.5 & 36.7 \\
Upper Denmark River & -48.6 & -89.8 & - \\
Yate Flat Ck & -57.5 & -58.0 & - \\
\hline
\end{tabular}

Catchments with perennial streamflow showed relatively uniform reduction across their flow distribution, whereas catchments with ephemeral streamflow showed more dramatic reduction in low flows, leading to increased number of zeroflow days (e.g. Burnt Out Creek). Characteristic flows such as high flows $\left(Q_{5}\right)$, median flows $\left(Q_{50}\right)$ and low flows $\left(Q_{95}\right)$ are defined as the daily flows exceeded 5,50 and $95 \%$ of the time, respectively. Relative reductions in these flows are listed in Table 2. For most of the catchments, average flow reduction was about $45 \%$ for high and median flows. The reduction in low flow was greater. Burnt Out Creek, Pine Creek, and Red Hill showed much more dramatic changes in these characteristic flows than the other catchments. These changes may be related to catchment size and level of plantation expansion.

\subsection{Comparison of estimates of mean annual streamflow reduction}

As described in Sect. 2.2, FCFC predicts the mean annual streamflow reduction using the method of Zhang et al. (2001), and this change in mean annual flow forms the basis of the FCFC methodology. Figure 6 compares estimates of mean annual streamflow reduction using the method of Zhang et al. (2001) and the time-trend analysis method. It can be seen that the methods provide reasonably similar estimates of plantation impact on mean annual streamflow. Average annual rainfall for the whole pre- and post-treatment periods was used in this calculation and this may introduce some error, especially for catchments with a relatively large rainfall difference over the two periods.

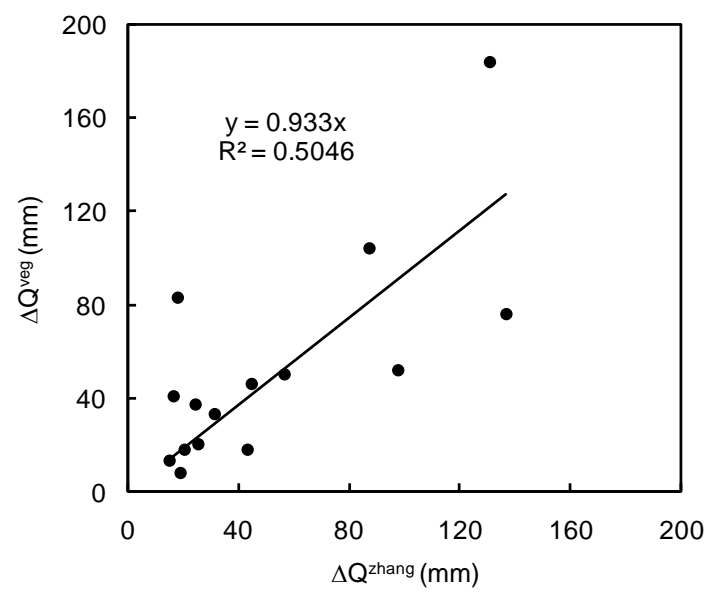

Fig. 6. Comparison between estimates of mean annual streamflow reductions using FCFC ( $\left.\Delta Q^{\text {zhang }}\right)$ and the time-trend analysis method $\left(\Delta Q^{\text {veg }}\right)$.

\subsection{Comparison between predicted and observed FDCs}

Figure 7 shows comparisons between FCFC predicted and observed FDCs for the selected catchments in the posttreatment period. Table 3 provides a summary of results for all the catchments. It is clear that most catchments showed good agreement between the predictions and observations. The model underpredicted the cease-to-flow (CTF) percentile or overestimated the number of zero-flow days in several catchments, for example, the predicted CTF is $48 \%$ for Yate Flat Creek, while observed value is $67 \%$. However, the model overpredicted CTF in Red Hill. In 13 of the 15 the catchments, the direction of change and the shape of the predicted FDC are consistent with the changes observed between the pre-treatment and post-treatment conditions. For the Bombala River and Traralgon Creek catchments, the predicted change in the FDC is not consistent with the observed change in shape between pre- and post-treatment condtions. Investigation into the causes showed that the bucket model of the FCFC methodology does not capture the low flows well in the calibtation period. This results in an overestimation of the number of zero flow days or underestimated low flows. The impact of this is that the model overestimated the high flows to compensate for the lack of flow flows so that a mass balance could be achieved. This indicates the importance of assessing the bucket model fit during the calibration phase of FCFC to ensure the low flows are being adequately modelled. There is a strong correlation between predicted and observed median (see Table 3). The results in Fig. 7 and Table 3 show that the FCFC model works well with 13 of the 15 catchments having coefficient of efficiency greater than 0.8 . 

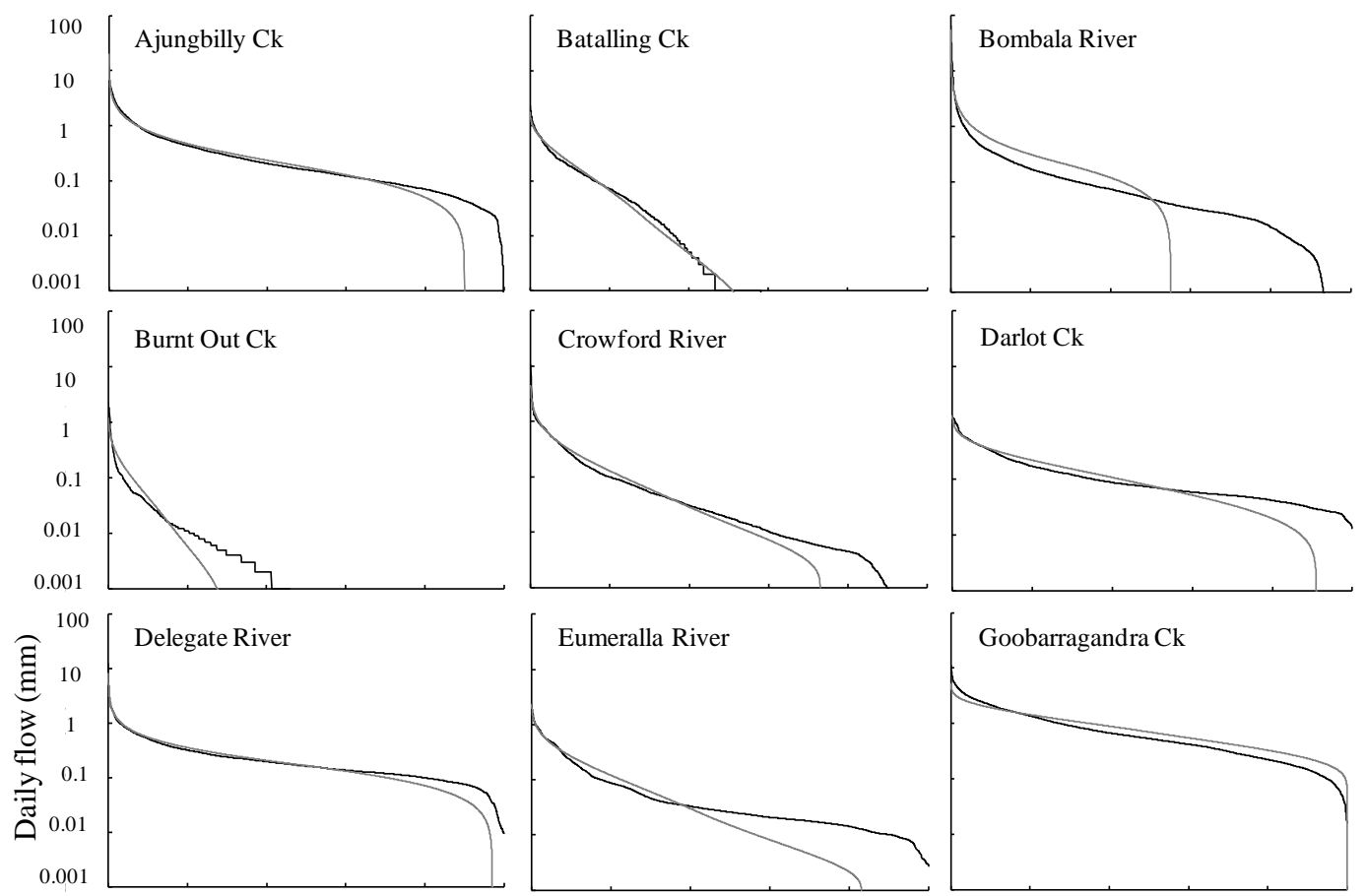

Goobarragandra $\mathrm{Ck}$
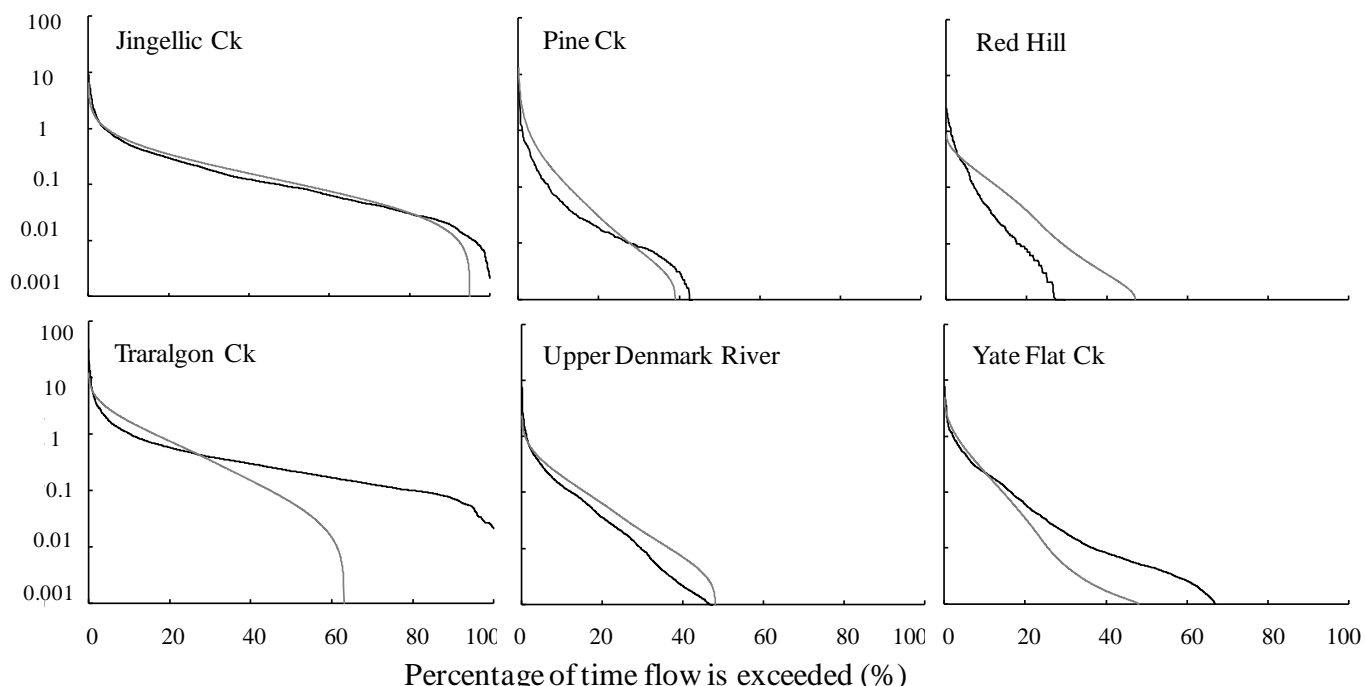

Fig. 7. Comparisons of FCFC predicted and observed flow duration curves for the selected catchments in the post-treatment period. The black lines represent observed flow duration curves, and the grey lines represent predicted flow duration curves.

\section{Discussion}

Increasing plantation cover reduces total streamflow as well as changes streamflow regime. After plantation expansions, catchments with perennial streamflow in the pre-treatment periods showed relatively uniform reductions across most flows, whereas catchments with ephemeral streamflow regime showed more dramatic reductions in low flows, leading to increased number of zero-flow days. Although proportional reductions in high flow are small, they represent large volume changes. The low flows showed greater proportional reductions but with smaller volume changes. The perennial catchments have more uniform temporal rainfall distribution and lower index of dryness. The combined effect of these factors means the soil water store in these catchments drained more slowly, maintaining baseflow throughout the year. For example, Traralgon Creek has an index of dryness of 0.86, representing a wet and perennial catchment. The soil depth of the catchment is over $2 \mathrm{~m}$ with soil water storage capacity of $270 \mathrm{~mm}$, as estimated by McKenzie et al. (2000). The flow from the catchment remained perennial despite relatively large proportional plantation expansion. On the other hand, 
Table 3. Results of FCFC predictions against observations using measured change in mean annual streamflow.

\begin{tabular}{lrrllc}
\hline Catchment & $\begin{array}{r}\text { CTF } \\
\text { predicted }\end{array}$ & $\begin{array}{r}\text { CTF } \\
\text { observed }\end{array}$ & $\begin{array}{l}\text { Median } \\
\text { predicted }\end{array}$ & $\begin{array}{l}\text { Median } \\
\text { observed }\end{array}$ & $\begin{array}{c}\text { Coefficient of } \\
\text { efficiency }\end{array}$ \\
\hline Adjungbilly Ck & 90 & 100 & 0.203 & 0.158 & 0.96 \\
Batalling Ck & 51 & 47 & 0.034 & 0.053 & 0.99 \\
Bombala River & 55 & 93 & 0.218 & 0.056 & 0.86 \\
Burnt Out Ck & 28 & 41 & 0.021 & 0.010 & 0.90 \\
Crawford River & 73 & 90 & 0.037 & 0.024 & 0.96 \\
Darlot Ck & 91 & 100 & 0.087 & 0.071 & 0.86 \\
Delegate River & 97 & 100 & 0.172 & 0.164 & 0.96 \\
Eumeralla River & 83 & 100 & 0.027 & 0.026 & 0.91 \\
Goobarragandra Ck & 100 & 100 & 0.705 & 0.537 & 0.94 \\
Jingellic Ck & 95 & 100 & 0.120 & 0.091 & 0.96 \\
Pine Ck & 41 & 43 & 0.01 & 0.02 & 0.99 \\
Red Hill & 47 & 27 & 0.022 & 0.022 & 0.80 \\
Traralgon Ck & 63 & 100 & 0.306 & 0.222 & 0.64 \\
Upper Denmark & 48 & 47 & 0.040 & 0.024 & 0.93 \\
Yate Flat Ck & 48 & 67 & 0.014 & 0.013 & 0.95 \\
\hline
\end{tabular}

the ephemeral catchments are relatively dry catchments with the index of dryness greater than unity. These catchments have winter dominated rainfall and are small in size. During the dry period (i.e. summer), soil water store of the catchments drained quickly, leading to zero flows. The presence of plantation in these catchments enhanced evapotranspiration and lowered soil water levels significantly. As a result, substantial proportional reductions occurred in the low flows with an increased number of zero-flow days. For example, the Upper Denmark River has an index of dryness of 1.36 with a strong winter-dominant rainfall. During summer, average monthly rainfall is about $25 \mathrm{~mm}$, while potential evaporation exceeds $100 \mathrm{~mm}$. The catchment has shallow (i.e. less than $1.0 \mathrm{~m}$ ) duplex sandy gravel soil with a permeability of $28 \mathrm{~mm} \mathrm{~h}^{-1}$ (Bari et al., 2004). After the plantation development, low flows in the catchment reduced considerably with greater number of zero-flow days (see Fig. 5).

The FCFC methodology was developed for a practical purpose, namely predicting changes in flow duration curves following plantation expansions with limited data available. As a result, the model is simple in its process representation and requires minimum input data. One of the key components of FCFC is the method of Zhang et al. (2001) for estimating differences in mean annual streamflow under different degrees of forest cover. The method of Zhang et al. (2001) has been widely used (Jackson et al., 2005; Sun et al., 2006) and a number of studies tested its accuracy using data from experimental catchments (Brown et al., 2005; Zhao et al., 2010). Brown et al. (2005) compared estimated changes in mean annual streamflow using the method of Zhang et al. (2001) with those observed from paired catchment studies, and showed that the method of Zhang et al. (2001) yielded good estimates of the changes in mean annual streamflow from catchments involving conifer and eucalyptus. Zhao et al. (2010) evaluated methods for estimating the effects of vegetation cover change on streamflow using paired catchment data from Australia, New Zealand, and South Africa. The study showed that the method of Zhang et al. (2001) provided consistent estimates of vegetation impact on mean annual streamflow compared with paired catchment method and time-trend analysis method. However, one of the limitations of these studies is that the catchments used to test the method of Zhang et al. (2001) are small headwater catchments. To overcome the limitation, this study further tested the method of Zhang et al. (2001) with data from 15 Australian catchments that have undergone plantation expansions. Unlike paired catchments that are generally less than $1 \mathrm{~km}^{2}$ in area, these catchments represent the typical area of catchments where plantation and water resources decisions are made. These catchments range in size from 0.6 to $1136 \mathrm{~km}^{2}$, and represent different climatic conditions and plantation management practices. The results showed that predicted mean annual streamflow reductions by the method of Zhang et al. (2001) agree reasonally well with estimates using timetrend analysis method. This provides confidence in using Zhang et al. (2001) for estimating changes in mean annual streamflow within FCFC.

The FCFC model uses flow duration curve (FDC) to describe streamflow regime, and this is convenient as the area under the FDC is equal to the mean annual streamflow, which can be predicted by method of Zhang et al. (2001) (Brown et al., 2005). The FCFC model is sensitive to errors in the estimated change in mean annual streamflow. This is because the key parameters (the median and CTF or 95th percentile flow) are dependent on the estimated mean annual streamflow. For example, if the method of Zhang et al. (2001) overestimates the reduction in streamflow as the result of a forest cover change, FCFC is likely to underestimate the CTF point or 
95th percentile flow. Conversely, if the method of Zhang et al. (2001) underestimates the change in mean annual streamflow, the 95th percentile flow is likely to be overestimated. However, the FCFC model can be used with estimates of mean annual streamflow change from any models or observations. In this study, the observed change in mean annual streamflow was used and it allows a direct comparision between the FCFC modelled and the observed FDC during the post-treatment period. Such a comparison enables us to separate the effect of errors in mean annual streamflow on FDC prediction from that of the FCFC parameterisation.

The bucket model used to adjust the low flow section of the FDC (the CTF or 95th percentile flow) aims to provide a simple procedure to adjust the percentage of time flow occurs in a catchment. The results shown in Fig. 7 indicate that the bucket model underestimated the CTF or 95th percentile flow in some catchments. It is possible that when applied to large catchments, the bucket model needs some improvement to reflect differences in baseflow response to forest cover change. Brown (2008) showed that the simple bucket model used in the FCFC does a satisfactory job of predicting the change in the CTF percentile in small paired catchments. Adjusting the bucket for a change in land use (using the mass balance) relies on the assumption that, apart from the change in plant available water storage, there is no change in other soil properties following a change in vegetation cover. Thus, the amount of soil moisture when the soil is saturated does not change following a change in vegetation cover and the recession constant remains the same. In reality, it is possible that the soil properties will change following a change in vegetation. However, it is thought that the impact of these changes is likely to be insignificant compared to the changes in rooting depth or plant available water storage.

It is known that plantation water use increases with its age till it reaches a maximum, and this process is generally accompanied by increasing streamflow reductions (Scott and Smith, 1997). FCFC only considers two hydrological equilibrium states of a catchment represented by pre-treatment and post-treatment vegetation covers. In other words, FCFC predicts changes in flow duration curves from pre-treatment equilibrium state to post-treatment equilibrium state. The equilibrium state is generally associated with a stable vegetation cover and climatic conditions. This assumption may not be strictly valid in some of the catchments used in this study due to uncertainty of plantation age, short pre-treatment flow data, and thinning. The time required from pre-treatment equilibrium state to post-treatment equilibrium state varies between 5 and $15 \mathrm{yr}$ for eucalyptus plantation in South Africa (Scott and Smith, 1997). Zhao et al. (2012) reported consistent estimates of plantation age effect on streamflow for catchments in Australia. Lane et al. (2005) investigated changes in flow duration curves in relation to plantation age and found similar results. These studies indicate that plantation age is an important factor in determining plantation impact on streamflow. For the catchments reported in this study, the pre- and post-treatment periods were selected to acknowledge the plantation age effect. For the small catchments such as Red Hill, plantation development took place in one stage and the post-treatment was chosen as 2001 to 2005 , representing average plantation age of $14 \mathrm{yr}$. However, for large catchments plantation development took place in several stages over a period of many years. It is difficult to determine plantation age in these catchments. To minimize the plantation age effect, the post-treatment period was selected with relatively mature plantation cover. Apart from plantation age, management of plantations such as thinning can also affect streamflow. Webb and Kathuria (2012) showed that thinning of the plantation in Red Hill in 2003 had a noticeable effect on streamflow. These factors would affect the accuracy of FCFC predictions. Another important factor in estimating plantation impact on streamflow is rainfall, and in general the post-treatment period was drier than the pre-treatment period. FCFC incorporated this effect by using average rainfall during the post-treatment period for each catchment.

\section{Summary}

Plantation reduces streamflow volume and changes streamflow regime. Catchments with perennial streamflow in the pre-treatment periods showed relatively uniform reductions in most flows after plantation expansions, whereas catchments with ephemeral streamflow showed more dramatic reductions in low flows, leading to increased number of zeroflow days. Proportional reductions are small in high flows and large in low flows. However, the changes in high flow represent larger volume reductions. These changes in high and low flows following plantation development have different implications for water resources management and environmental flows. The Forest Cover Flow Change model (FCFC) was developed to adjust a time series of observed or simulated daily flow to account for significant changes in forest cover. The model assumes that the method of Zhang et al. (2001) is accurate for predicting changes in mean annual streamflow following plantation expansions, and it predicts the CTF percentile or 95th percentile by solving a simple bucket model. It is also assumed that, apart from the change in plant available water storage, there is no change in other soil properties following a change in vegetation cover. FCFC is designed for hydrologists, engineers, policy makers, and managers in consultancies and state agencies involved in water resources and plantation management and planning. FCFC is only appropriate for predicting changes in streamflow following changes in forest cover and is not appropriate for other land-use changes. The model is not applicable to catchments with significant irrigation or water extraction. FCFC has been validated in small catchments in Australia and South Africa. This study showed that the model is applicable to large catchments as well. This provides users 
with a means of identifying the change in streamflow regime due to changes in forest cover. FCFC can be used in larger catchment models to look at downstream impact of plantation expansions.

Acknowledgements. We thank Mark Parsons, Mark Foreman, Darryl Harvey, Luke Esprey, Kumar Savadamuthu, Alexander Nguyen, Ian White, Ashley Webb, Ray Boyton, Jason Hill, Geoff Quinn, Garry Carr, Ken Bubb, Ray Maynard, Duncan Watt, Ian Frake, Craig Clifton, Don McGuire, and Jai Vaze for helping with catchment selection and providing streamflow and plantation data. We also thank Stephen Elliott, Greg Day, and other members of the Steering Committee for their inputs. The project was funded through the National Water Commission, CSIRO and Forest \& Wood Products Australia (FWPA) Project: "Methods to Accurately Assess Water Allocation Impacts of Plantations". We would like to thank Richard Silberstein and Junguo Liu for their constructive comments on the paper. We would also like to thank three anonymous reviewers for the valuable comments and suggestions.

\section{Edited by: J. Liu}

\section{References}

Bari, M. A. and Ruprecht, J. K.: Water yield response to land use change in south-west Western Australia, Department of Environment, Salinity and Land Use Impacts Series Report No. SLUI 31, http://www.water.wa.gov.au/PublicationStore/first/ 43766.pdf, last access: 20 May 2012, Perth, Western Australia, 2003.

Bari, M. A., Mauger, G. W., Dixon, R. N. M., Boniecka, L. H., Ward, B., Sparks, T., and Waterhouse, A. M.: Salinity situation statement: Deanmark River, Water Resource Technical Series No. WRT 30, http://www.water.wa.gov.au/PublicationStore/first/ 40468.pdf, last access: 20 May 2012, Perth, Western Australia, 2004.

Baron, J. S., Hartman, M. D., Kittel, T. G., Band, I. E., Ojima, D. S., and Lammers, R. B.: Effects of land cover, water redistribution, and temperature on ecosystem processes in the South Platte Basin, Ecol. Appl., 8, 1037-1051, 1998.

Best, A. E., Zhang, L., McMahon, T. A., and Western, A. W.: Development of a model for predicting the changes in flow duration curves due to altered land use conditions, in Proceedings of MODSIM 2003 International Congress on Modelling and Simulation, http://www.mssanz.org.au/MODSIM03/ Media/Articles/Vol\%202\%20Articles/861-866.pdf, last access: 20 May 2012, Modelling and Simulation Society of Australia and New Zealand, Townsville, Queensland, Australia, 1417 July 2003, 861-866, 2003.

Bosch, J. M. and Hewlett, J. D.: A review of catchment experiments to determine the effect of vegetation changes on water yield and evapotranspiration, J. Hydrol., 55, 3-23, 1982.

Brown, A. E.: Predicting the effect of forest cover changes on flow duration curves, $\mathrm{PhD}$ thesis, The University of Melbourne, Melbourne, Australia, 2008.
Brown, A. E., Zhang, L., McMahon, T. A., Western, A. W., and Vertessy, R. A.: A review of paired catchment studies for determining changes in water yield resulting from alterations in vegetation, J. Hydrol., 310, 28-61, 2005.

Brown, A. E., McMahon, T. A., Podger, G. M., and Zhang, L.: A methodology to predict the impact of changes in forest cover on flow duration curves, CSIRO Land and Water Science Report 8/06, http://www.clw.csiro.au/publications/science/2006/ sr8-06.pdf, last access: 20 May 2012, CSIRO, Canberra, Australia, 2006.

Brown, A. E., Podger, G. M., Davidson, A. J., Dowling, T. I., and Zhang, L.: Predicting the impact of plantation forestry on water users at local and regional scales, An example for the Murrumbidgee River Basin, Australia, Forest Ecol. Manage., 251, 82-93, 2007.

BRS.: Australia's plantations 2009 inventory update, Department of Agriculture, Fisheries and Forestry, Bureau of Rural Sciences, Canberra, 2009.

Feikema, P., Beverly, C., Morris, J., Collopy, J., Baker, T., and Lane, P. N. J.: Predicting and managing the impacts of commercial plantations on catchment water balances, Forest and Wood Products Australia, Project number: PN04.4009, 64 pp., http://www.fwpa.com.au/sites/default/ files/PN04_4009_impact_of_comm_plantations.pdf, last access: 20 May 2012, Melbourne, Australia, 2008.

Grayson, R. B., Argent, R. M., Nathan, R. J., McMahon, T. A., and Mein, R. G.: Hydrological recipes: estimation techniques in Australian hydrology, Cooperative Research Centre for Catchment Hydrology, Melbourne, Victoria, 1996.

Greenwood, A. J. and Cresswell, D. J.: The impact of plantation forestry on runoff in the Mount Lofty Ranges, Case study: Burnt Out Creek, Department of Water, Land and Biodiversity Conservation Technical Note TN2007/11, https://www.waterconnect. sa.gov.au/BusinessUnits/InformationUnit/Technical\% 20Publications/ki_dwlbc_technical_note_2007_11a.pdf, last access: 20 May 2012, Adelaide, Australia, 2007.

Haines, A. T., Finlayson, B. L., and McMahon, T. A.: A global classification of river regimes, Appl. Geogr., 8, 255-272, 1988.

Hundecha, Y. and Bárdossy, A.: Modelling of the effect of land use change on the runoff generation of a river basin through parameter regionalization of a watershed model, J. Hydrol., 292, 281295, 2004.

Jackson, R. B., Jobbagy, E. G., Avissar, R., Roy, S. B., Barrett, D. J., Cook, C. W., Farley, K. A., Maitre, D. C. L., McCarl, B. A., and Murray, B. C.: Trading water for carbon with biological caron sequestration, Science, 310, 1944-1947, 2005.

Jeffrey, S. J., Carter, J. O., Moodie, K. M., and Beswick, A. R.: Using spatial interpolation to construct a comprehensive archive of Australian climate data, Environ. Modell. Softw., 16/4, 309330, 2001.

Lane, P. N. J., Best, A. E., Hickel, K., and Zhang, L.: The response of flow duration curves to afforestation, J. Hydrol., 310, 253-265, 2005.

Lee, R.: Forest Hydrology, Columbia Univ. Press, New York, 349 pp., 1980.

Legesse, D., Vallet-Coulomb, D., and Gasse, F.: Hydrological response of a catchment to climate and land use changes in Tropical Africa: case study South Central Ethiopia, J. Hydrol., 275, 67-85, 2003. 
Linke, G. K., Seker, M., and Livingston, M.: Effect of reafforestation stream flows, salinities and groundwater levels in the Pine Creek catchment, Murray Darling 1995 Workshop Extended Abstracts, Wagga Wagga, Australian, 11-13 September 1995.

Major, E. J., Cornish, P. M., and Whiting, J. K.: Red Hill hydrology project establishment report including a preliminary water yield analysis, Research Paper No. 36, Forest Research and Development Division, State Forests of New South Wales, Sydney, 24 pp., 1998.

McKenzie, N. J., Jacquier, D. W., Ashton, L. J., and Cresswell, H. P.: Estimation of soil properties using the Atlas of Australian Soils, Technical Report 11/00, CSIRO Land and Water, Canberra, ACT, 24 pp., 2000.

Nash, J. E. and Sutcliffe, J. V.: River flow forecasting through conceptual models, Part I - A discussion of principles, J. Hydrol., 10, 282-290, 1970.

Sanborn, S. C. and Bledsoe, B. P.: Predicitng streamflow regime metrics for ungauged streams in Colorado, Washington and Oregon, J. Hydrol., 325, 241-261. 2006.

Scott, D. F. and Smith, R. E.: Preliminary empirical models to predict reductions in total and low flows resulting from afforestation, Water SA, 23, 134-140, 1997.

Sivapalan, M., Ruprecht, J. K., and Viney, N. R.: Water and salt balance modelling to predict the effects of land-use changes in forested catchments, 1. Small catchment water balance model, Hydrol. Process., 10, 393-411, 1996.

Smakhtin, V. Y.: Generation of natural daily flow time-series in regulated rivers using a non-linear spatial interpolation technique, Regul. Rivers: Res. Mgmt., 15, 311-323, 1999.

Smakhtin, V. Y.: Low flow hydrology: a review, J. Hydrol., 240, 147-186, 2001.
Sun, G., Zhou, G. Y., Zhang, Z. Q., Wei, X. H., McNulty, S. G., and Vose, J. M.: Potential water yield reduction due to forestation across China, J. Hydrol., 328, 548-558, 2006.

Tuteja, N. K., Vaze, J., Teng, J., and Mutendeudzi, M.: Partitioning the effects of pine plantations and climate variability on runoff from a large catchment in southeastern Australia, Water Resour. Res., 43, W08415, doi:10.1029/2006WR005016, 2007.

van Dijk, M. H.: Reduction in evaporation due to the bird screen used in the Australian class A pan evaporation network, Aust. Meteorol. Mag., 33, 181-183, 1985.

Webb, A. A. and Kathuria, A.: Response of streamflow to afforestation and thinning at Red Hill, Murray Darling Basin, Australia, J. Hydrol., 412-413, 133-140, 2012.

Wei, X. H. and Zhang, M. F.: Quantifying streamflow change caused by forest disturbance at a large spatial scale: A single watershed study, Water Resour. Res., 46, W12525, doi:10.1029/2010WR009250, 2010.

Zhang, L., Dawes, W. R., and Walker, G. R.: Response of mean annual evapotranspiration to vegetation changes at catchment scale, Water Resour. Res., 37, 701-708, 2001.

Zhang, L., Zhao, F. F., Chen, Y., and Dixon, R. N. M.: Estimating effects of plantation expansion and climate variability on streamflow for catchments in Australia, Water Resour. Res., 47, W12539, doi:10.1029/2011WR010711, 2011.

Zhao, F. F., Zhang, L., Xu, Z. X., and Scott D. F.: Evaluation of methods for estimating the effects of vegetation change and climate variability on streamflow, Water Resour. Res., 46, W03505, doi:10.1029/2009WR007702, 2010.

Zhao, F. F., Xu, Z. X., and Zhang, L.: Changes in streamflow regime following vegetation changes from paired catchments, Hydrol. Process., 26, 1561-1573, doi:10.1002/hyp.8266, 2012. 